\title{
A One Century Record of Changes at Nenskra and Nakra River Basins Glaciers, Causasus Mountains, Georgia
}

\author{
Levan G. Tielidze, Lela Gadrani, Roman Kumladze \\ Vakhushti Bagrationi Institute of Geography, Ivane Javakhishvili Tbilisi State University, Tbilisi, Georgia \\ Email: levan.tielidze@tsu.ge, levani.tielidze@gmail.com
}

Received 28 February 2015; accepted 18 March 2015; published 20 March 2015

Copyright $@ 2015$ by authors and Scientific Research Publishing Inc.

This work is licensed under the Creative Commons Attribution International License (CC BY). http://creativecommons.org/licenses/by/4.0/ (c) (i) Open Access

\begin{abstract}
The article considers the variability of Nenskra and Nakra River basins glaciers' parameters in the years of 1911-2014. Nenskra and Nakra River basins are located on the southern slope of the Great Caucasus, between the Kharikhra, Shdavleri and Tsalgmili ranges, in Georgia, in particular in the Enguri River basin. In our research we used the catalogue of the glaciers of Georgia compiled by K. Podozerskiy in 1911. We also used the military topographic maps with the scale of 1:25,000 and 1:50,000 drawn up in 1960 (in former Soviet Union), where there are the glaciers mapped in detail and the ends of their ice tongues on the southern slope of Great Caucasus of those times. We also used the remote sensing method, which is the best modern way for the study of the dynamics of glaciers and this method is remarkable by a quick obtaining of results. The spectral images of the Landsat L8 OLI/TIRS (Operational Land Imager and Thermal Infrared Sensor) (USGS) received from the "Landsat" artificial satellite are the necessary materials for our study. We also used the field survey materials of 2014 (GPS data). The latest statistical information is also given about the glaciers located in the individual river basins; their morphological types, exposition and the dynamics are considered according to the individual years.
\end{abstract}

\section{Keywords}

South Caucasus Glaciers, Glaciers of Georgia, Glaciers Dynamic, Remote Sensing

\section{Introduction}

Great attention is paid to the monitoring of glaciers in many countries, including their changing and observation on its regime, which is very interesting information to find out about the climate global change. Climate change 
and glacier dynamics studies in the Caucasus region are of great importance, because the Caucasus is one of the major mountain systems in Eurasia [1].

Glacial melt water is one of the main factors in river runoff formation in the mountainous areas of Georgia. Its erosive action is determined by the ablation intensity during the day. It is necessary to know glacial water's daily volatility for mountaineering, tourism and mountainous areas of livestock and other sectors of operation.

Hydropower enabling the country to export electric energy and boost its role in a country's income as well as building the hydroelectric station on the large rivers (Kodori, Enguri, Rioni, Tskhenistskali, Nenskra) is provided by hydro-resources. It is necessary to be considered in the design of hydroelectric power stations on the glacier water runoff character. As we said, glacial melt water plays an important role in the runoff, especially in the summer months. River flooding is directly linked to the growth of ablation and the retreat of glaciers tongues. Glacier melt water is also important in terms of water supply in mountainous regions of Georgia. In addition to the tourist's recreational purposes in mountainous regions (Svaneti, Kazbegi, Racha, Abkhazeti), a great role in the development of recreation facilities is owned by the glacial landscapes.

Research of glaciers has a long history in the southern slope of the Caucasus, namely in Georgia. The first scientific reports of the early XVIII century are given by a great Georgian scientist Vakhushti Bagrationi. Since 30s of the 20th century till today, the observation of the western, central and eastern Caucasus glaciers has been almost permanent. There are considerable amounts of data in the archives of the Vakhushti Bagrationi Institute of Geography, which help us to establish an accurate picture of the dynamics of glaciers.

At present there are 637 glaciers in Georgia. Modern glaciers are mainly concentrated in the Enguri, Rioni, Kodori and Tergi River basins. Main centers of glaciation are linked to upraised Caucasian watershed range and Kazbegi massif. There are also the separate centers in the branch ranges of the Caucasus: Bzipi, Kodori, Samegrelo, Svaneti, Lechkhumi, Khevsureti, Pirikita and others. The glaciers of all expositions can be found in Georgia today, and among the morphological types the following can be distinguished: compound-valley, simplevalley (with one or multi-cameral firn), cirque-valley, cirque-hanging and cirque glaciers [2].

\section{Study Area}

Nenskra and Nakra River basin are located on the southern slope of the Central Caucasus, in Upper Svaneti region, particular between the Kharikhra, Shdavleri and Tsalgmili Ranges (Figure 1).

Nenskra River basin is the largest by its area among the Enguri River tributaries. It occupies $625 \mathrm{sq} . \mathrm{km}$. $24.90 \%$ of the total amount of the glaciers of the Enguri River basin is the share of this basin and occupies the first place in the Enguri River basin in this regard. By the area of the glaciers it is behind the Mulkhura, Mestiachala and Dolra River basins and the Enguri headwaters. Morphometric and morpographical conditions of the relief of the Nenskra gorge cause the uneven distribution of the glaciers here. The valley type glaciers are mainly found in the right-hand tributary basins of the Nenskra River and on the north-western slope of the Shdavleri range. There are small cirque glaciers on the southern slope of the Great Caucasus.

Nakra River basin is one of the smallest in the Enguri River basin. Its area is 150 sq. km. The Nakra River basin is of meridional direction. To the west it is bounded by the Shdavleri range, to the east-by the Kvishi range (height of some peaks exceed $3900 \mathrm{~m}$ here), while to the north it is bounded by a small part of the Great Caucasus watershed range.

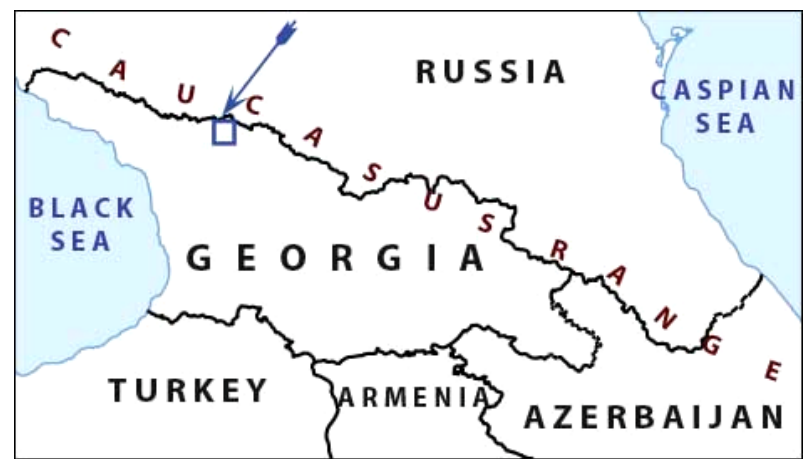

Figure 1. Location of the Nenskra and Nakra River basins. 
Upper Svaneti synoptic conditions favorable for the existence of glaciers (mainly air temperature and precipitation distribution) leads to the West processes. At this time barometric gradient is directed from the west (the Black Sea) to the east (the Caspian Sea) direction. If the process is strong, regardless of time of year, with the increase of altitude in the mountainous areas in the solid form of a pellet, which creates more favorable conditions for the accumulation of snow on the glaciers. Especially if the process is relatively long (several days) persisted. At this time the rate of glacier daily retreat is reduced and a low air temperature is fixed on the glacier surface.

Barometric gradient is directed from East (Caspian Sea) to West (Black Sea) direction during the eastern Synoptic processes. The influence of this current is less pronounced in the eastern and western Georgia, especially in the upper Svaneti.

One of the ice forming meteorogical element-precipitation is unevenly distributed in the territory of Georgia. The orography with the circulation of air masses makes the regime difficult. In addition, with the sea height increased there is solid precipitation and the air temperature vertical distribution features are added [3]. Their effectiveness is particularly apparent in the Enguri River basin where the height of the mountains in (average of 3700 - 4500 meters, a height of 5000 meters - the highest), slope aspect, distance from the sea form the basin the center of the glaciations.

\section{Data Sources and Methods}

In this research we used the catalogue and maps of glaciers compiled by K. Podozerskiy in 1911. Although in the mentioned maps in some cases there are mistakes made in visualization of areas and number of glaciers, but this is the most reliable and adequate source to get the information about the glaciers conditions of those times.

Military topographic maps with scale 1:25,000 and 1:50,000 drawn up by the Department of Geodesy and Cartography in the 1960s in the former Soviet Union, were also used in research, there are marked glaciers with ice tongue on the south slope of Grat Caucasus. The topographic maps are in Pulkovo-1942 projection, but with the help ArcGis we made georeferencing and registered in WGS 1984 projection after this perfectly tied to the coordinate system (projected coordinate system: WGS-1984-UTM-zone-38N).

Also the remote sensing method was used for the study of the dynamic of glaciers (to determine area change, glacier length and elevation the ice tongue) which is the best modern way and the distinguished results quickly. The spectral images of the Landsat L8 OLI/TIRS (Operational Land Imager and Thermal Infrared Sensor) (USGS) taken from "Landsat" satellite on August 2014, present the materials for our study. All of them case corresponds to the clear weather condition, when the impact of snow cover on glaciers and the absence of clouds helps to distinguish valuable objects on the earth's surface. Then composite band function was used and with the help ArcGis images were fixed with sequence of the 7-5-3. As a result of the use of this method, we have estimated the variability of Nenskra and Nakra River basins glaciers area 1911-1960-2014 years, as well as its ice tongue length and altitudinal variation during these years.

Last expedition was held on August 2014, during which ice tongue was marked with GPS (Global Position System 62 STC GARMIN).

It is important the existence of climate elements especially air temperature data to study the dynamics of glaciers. From the Hydro-Meteorological Department of the Ministry of Environment of Georgia, we managed and used to obtain the average daily air temperature data of Mestia weather station since 1961 till 2013 (Mestia is a center the Upper Svaneti where located Nenskra and Nakra River basins).

\section{Results and Discussions}

There were 54 glaciers in the Nenskra River basin by 1911. with the area of 50.54 sq. km [4]. By the data of the topographical maps of 1960 (R. Gobejishvili) the area of the glaciers was $48.62 \mathrm{sq}$. km and their number-75 [5]. Such variability of the glaciers was stipulated by the disappearance of small glaciers on the one hand and on the other - by their division during the valley glaciers retreating. And by the data of 2014 there are 67 glaciers with the total area of 25.58 sq. $\mathrm{km}$ [2].

The morphology of the relief of the Nenskra River gorge causes the existence of numerous small cirque glaciers here. This type of glaciers occupies $44.77 \%$ of the total number of the glaciers of the entire basin. Then comes the glaciers of cirque-valley (22.38\%) and valley types (19.40\%). We have the vice versa situation regarding the area occupied by them. Valley glaciers occupy $55.98 \%$ of the total area of the glaciers of the Nen- 
skra River basin, cirque-valley glaciers-25.99\% and cirque glaciers-14.69\%. The share of the other morphological types of glaciers is insignificant (Figure 2).

The glaciers of the Nenskra River gorge are mainly located in the Kharikhra and Shdavleri ranges, which are of submeridional directions, therefore, here prevail the glaciers of overall northern exposition both by the number and area; they occupy $53.73 \%$ of the total number and $59.81 \%$ of the total area of the glaciers of the entire basin (Figure 3).

Kharikhra and Shdavleri glaciers are distinguished in the Nenskra River basin y their morphological and morphometric features and dimensions.

Shdavleri glacier is a valley-type glacier of western exposition, its length is of $4.58 \mathrm{~km}$ and the area-2.31 sq. $\mathrm{km}$. In 1960 its area was $2.48 \mathrm{sq}$. km (Figure 4). The ice tongue ends at a heiht of $2730 \mathrm{~m}$. The glacier starts from the teo independent firns, which are located on the northern slope of the Mount Shdavleri (3994 m). The eastern firn is connected to the firn of the glaciers of the Nakra River. Two icefalls are developed at a whole length of the Shdavleri glacier, one-when flowing out from the firn and another - in the middle part of the tongue. The ice tongue is covered with the thin weathered material and is well expressed in the relief. The tongue ends by a pointed form. The lateral stade moraines well expressed on the both sides of the tongue protect it from contamination; inside the stade moraines there can be found the well expressed microstade moraine by which it is possible to identify the parameters of the glacier retreating. By the data of 2014 the area of the Shdavleri glacier is $2.31 \mathrm{sq} . \mathrm{km}$ and its ice tongue ends at a height of $2730 \mathrm{~m}$ above sea level.

By K. Podozerskiy there were 26 glaciers Nakra River basin with a total area of $20.24 \mathrm{sq}$. km. By the data of 1960 there were 31 glaciers with the area of $18.49 \mathrm{sq}$. km. Increasing in the number of glaciers and reduction in their area within the mentioned two periods were well subjected to the increase in number of the glaciers in the first part of the $20^{\text {th }}$ century in parallel with the reduction in the total area of the glaciers, but the picture is different in the last 54-year period. By the data of 2014 there are 28 glaciers in the basin with a total area of

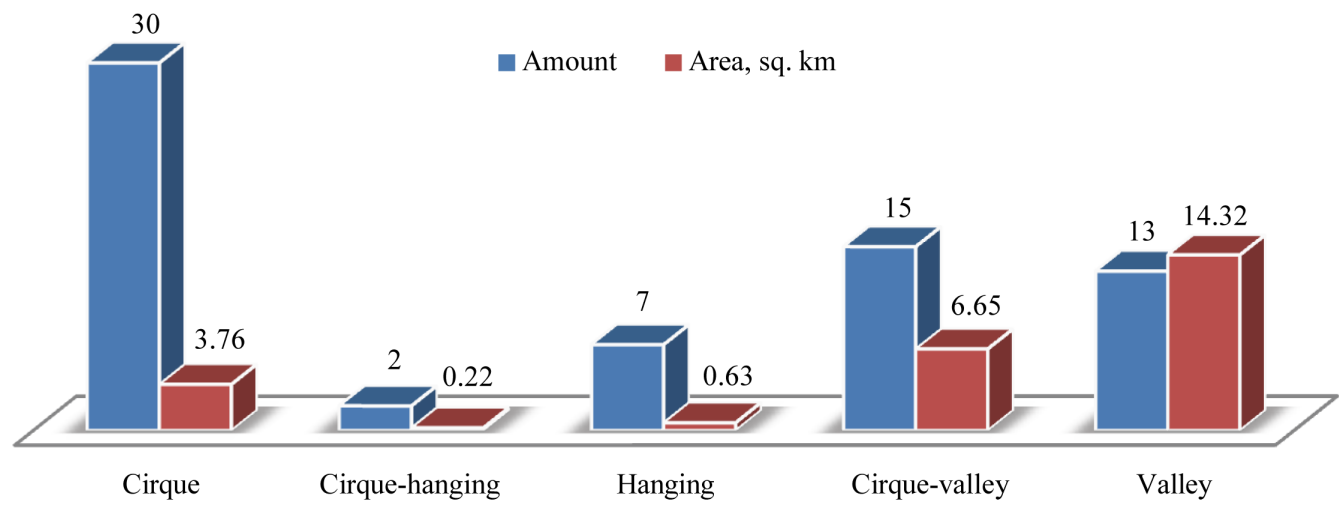

Figure 2. Distribution of the glaciers in the Nenskra River basin according to the morphological types.

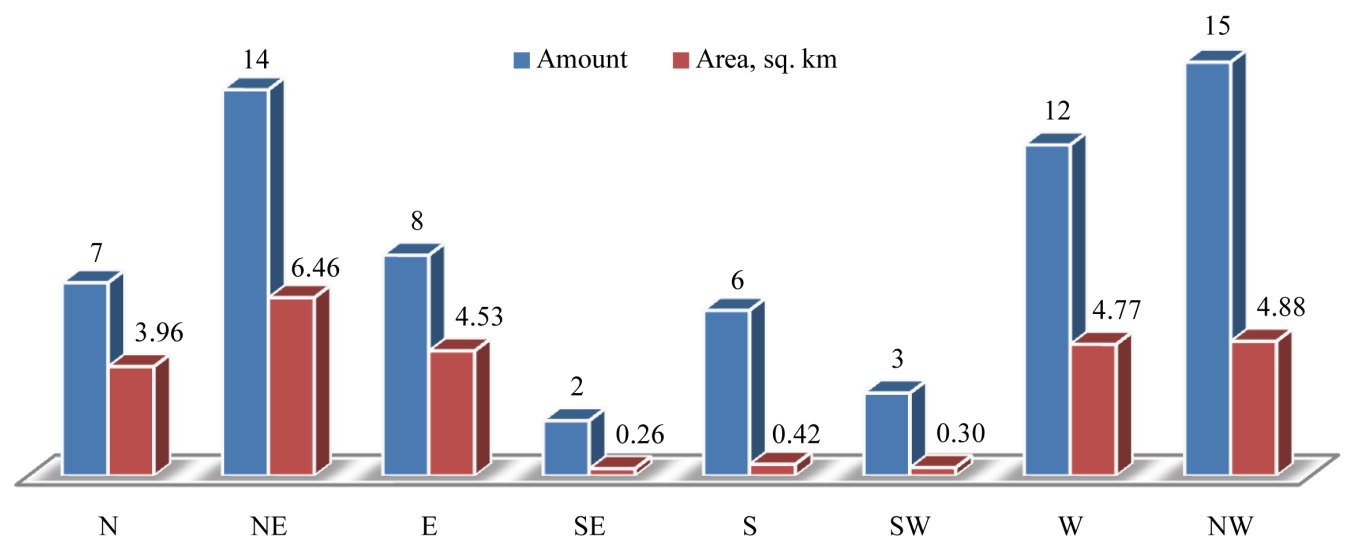

Figure 3. Distribution of the glaciers in the Nenskra River basin according to the exposition. 


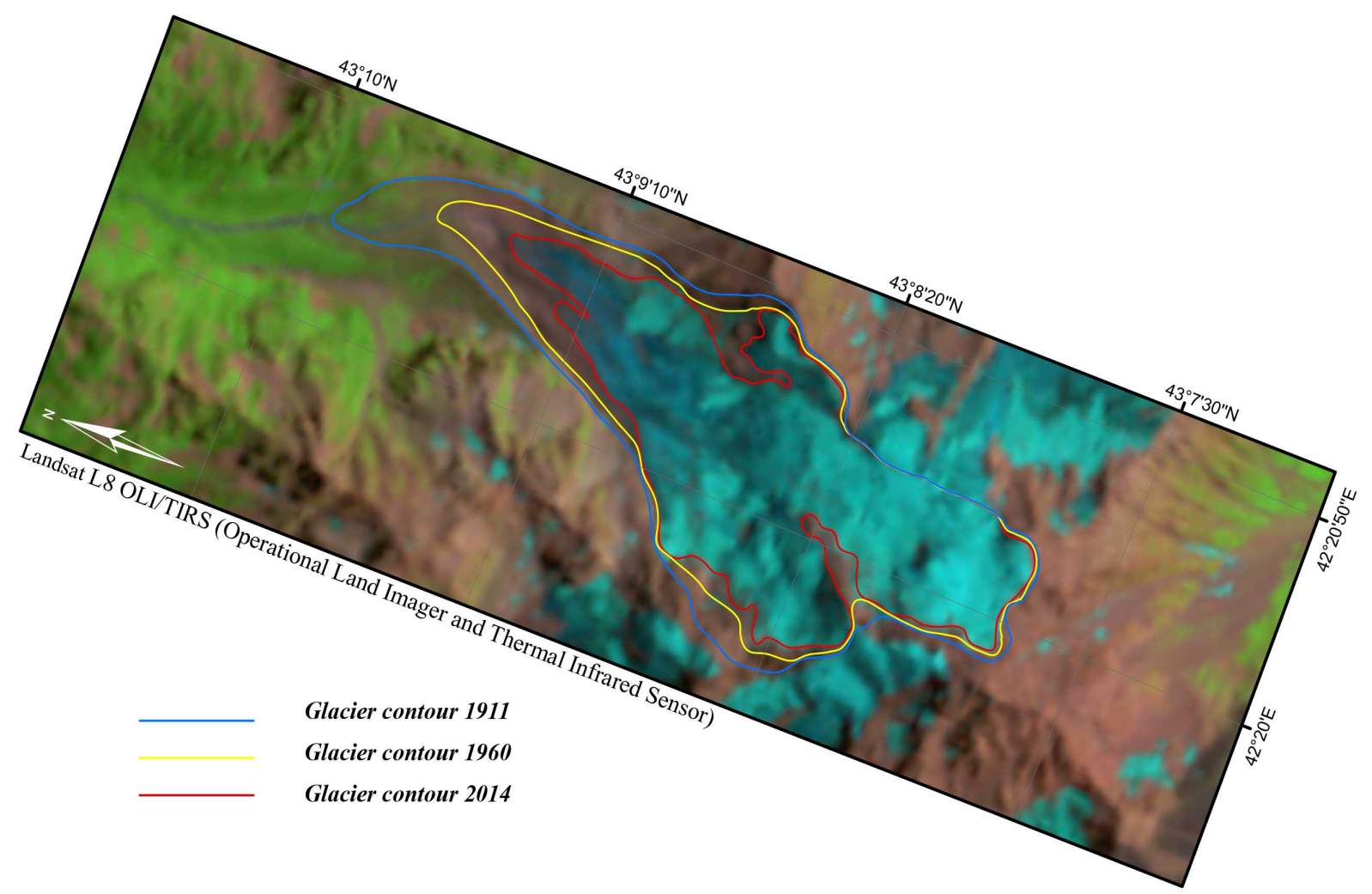

Figure 4. Shdavleri glacier retreat in 1911-1960-2014.

$10.21 \mathrm{sq}$. km. We can see that in this period the number of glaciers was decreased by 3 and the area was reduced by $44.79 \%$.

In the Enguri River basin the Nakra River basin is behind the rivers of Nenskra, Mulkhura and Dolra and the northern slope of the Svaneti range by the number of glaciers.

The ratio of the number and area of the glaciers indicates that there are basically the small cirque glaciers in this gorge. The glaciers are distributed by morphological types and exposition as follows (Figure 5, Figure 6).

The largest glaciers of the basin-the Nakra and Leadashti are located in the western slope of the Kvishi range.

Leadashti Glacier is the largest glacier in the Nakra River basin with an area of $3.47 \mathrm{sq}$. km. It is a valley type glacier and has an extensive firn field, the glacier tongue is clean and after flowing from the firn ends at the ledge. Its length is $5.63 \mathrm{~km}$. The ice tongue ends at a height of $3170 \mathrm{~m}$ above sea level. The firn exposition is southern, while the lower section of the firn and the tongue are of western direction. Due to grandiose ledge the glacier does not have the moraines. In early times the ice tongue had a form of an icefall and the loose material was collected at the bottom and ledge. The ice tongue overflows from the top of the ledge still today at a short distance. In 1960 the area of the Leadashti glacier was 4.29 sq. km. On this basis, we can specify that the glacier area was reduced by $19.11 \%$ in the years of $1960-2014$.

As for the Nakra glacier, its area was 2.02 sq. km in 1960 and 1.42 sq. km is in 2014. During this period its area was reduced by $29.70 \%$ (Figure 7 ).

As for the climate information, after our researches revealed that the air temperature is characterized by a positive trend. Maximum peaks are in July 1980, when the average temperature recorded $+19.1^{\circ} \mathrm{C}$ in Mestia respectively. The highest average monthly temperature $+20.1^{\circ} \mathrm{C}$ is fixed in July 2000 .

High temperatures are also in August, 2006, when $+19.6^{\circ} \mathrm{C}$ is fixed in Mestia. This data is the highest in average August temperatures for the $1960-2013$ years period. Also stands out August 2008 , when $+19.3^{\circ} \mathrm{C}$ is fixed in Mestia.

It should be noted that that in many cases the average temperature in July is higher than it is in August. Therefore we can say that July is the warmest month in our study area. 


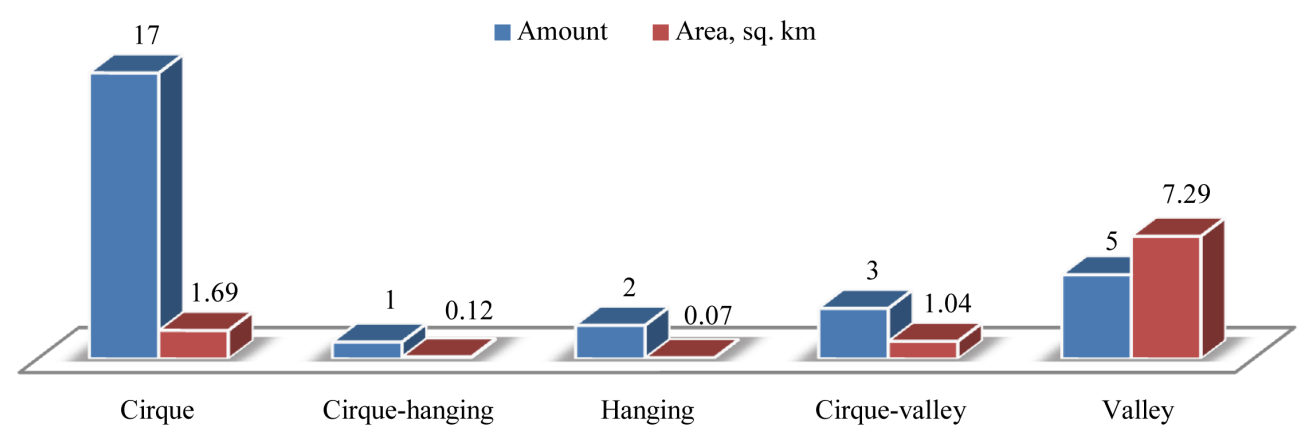

Figure 5. Distribution of the glaciers in the Nakra River basin according to the morphological types.

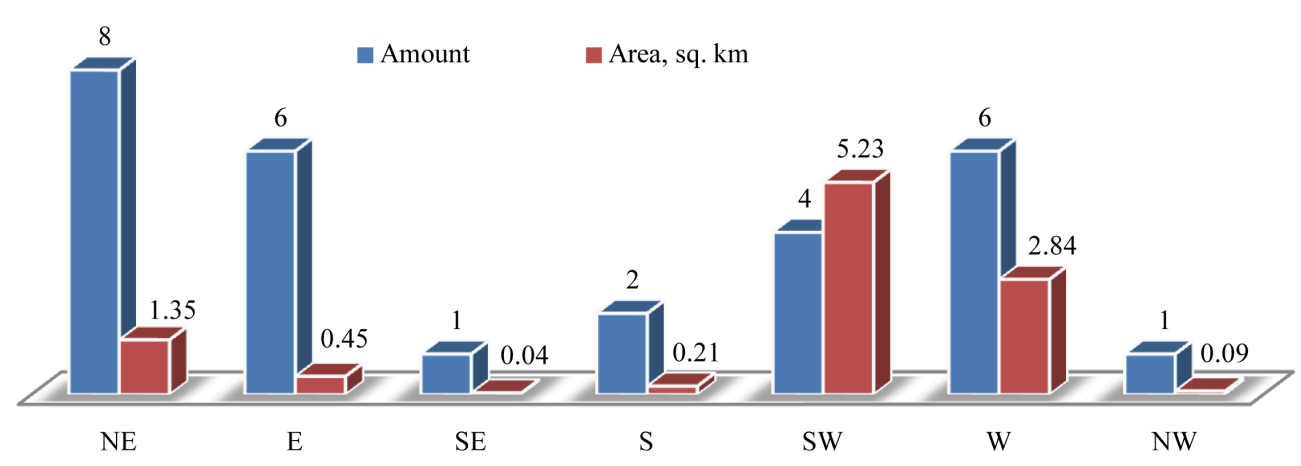

Figure 6. Distribution of the glaciers in the Nakra River basin according to the exposition.

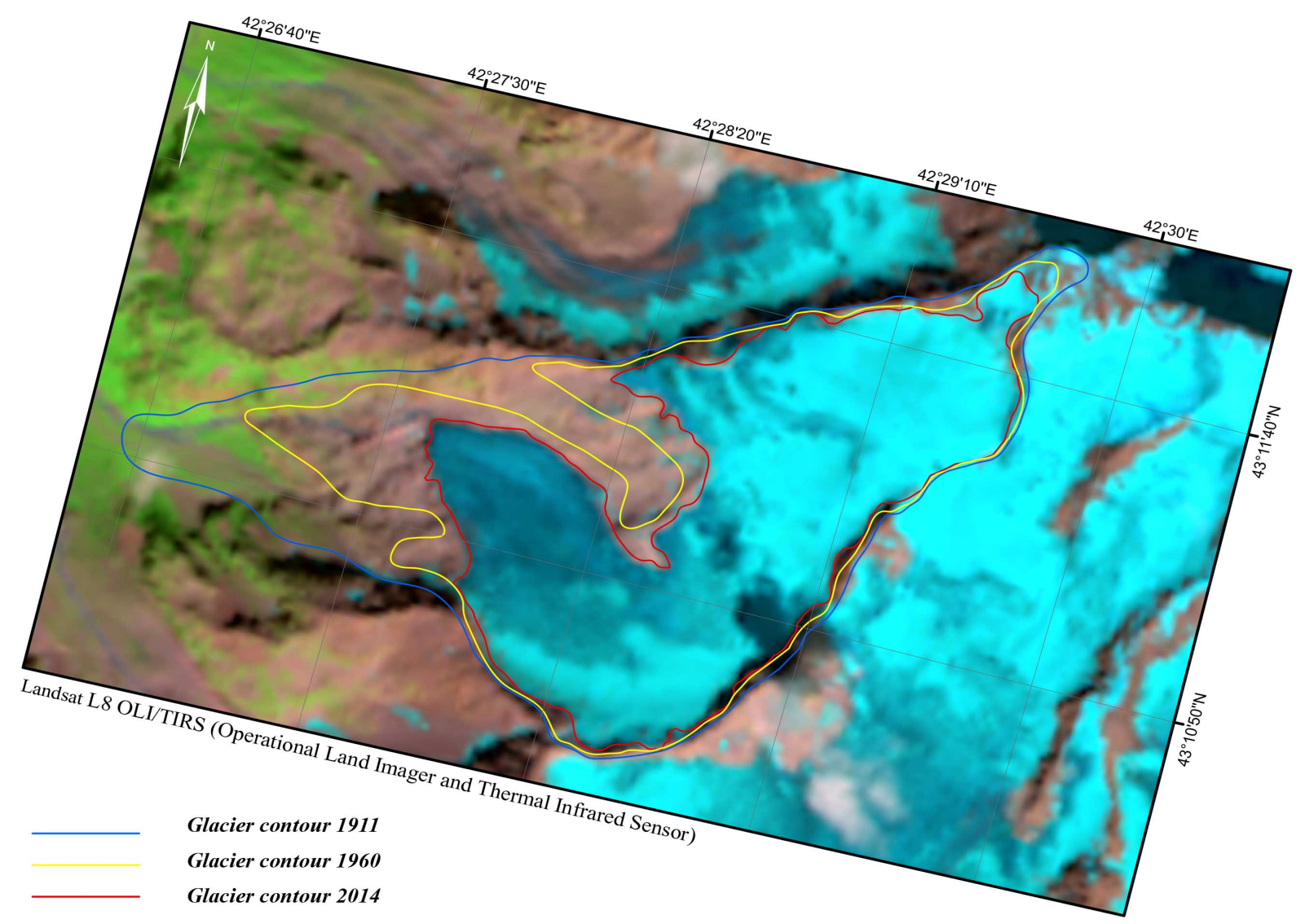

Figure 7. The retreat of Leadashti glaciers in 1911-1960-2014. 


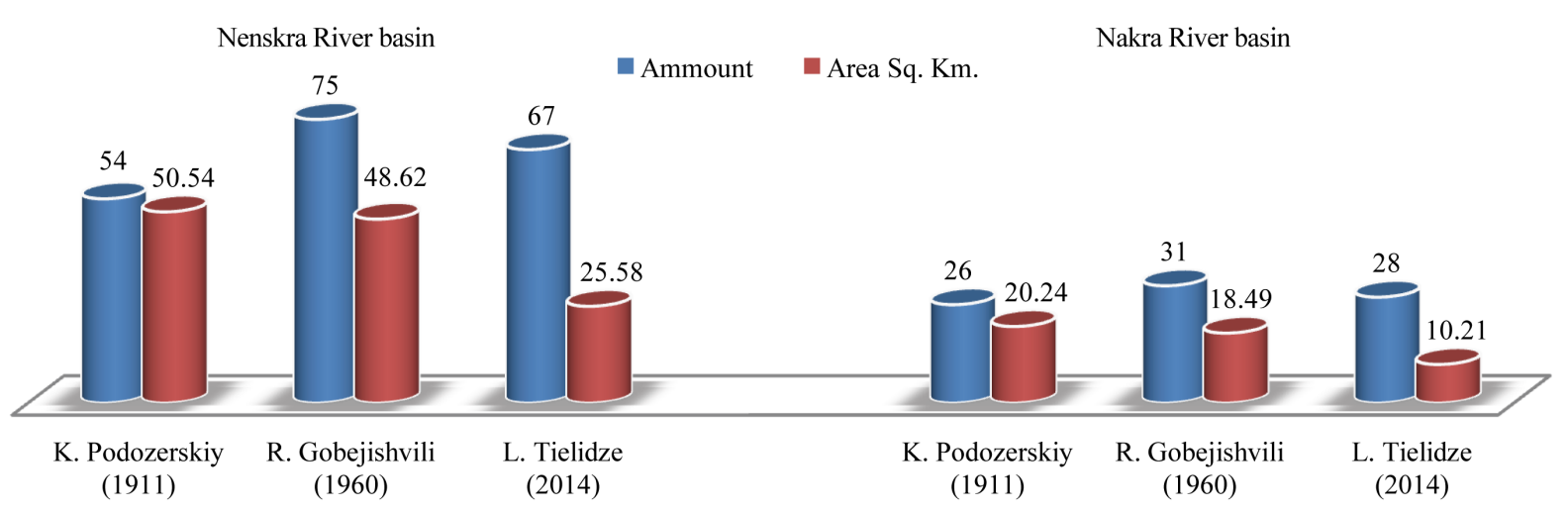

Figure 8. Dynamics of the glaciers in the Nenskra and Nakra River basins in 1911-1960-2014.

\section{Conclusions}

It is known that due to climate change, an intensive melting of glaciers is underway in every region of the contemporary world. The current glacial processes in the Caucasus, particularly, in Georgia, are one of the evidences of it. In general, in most cases as a result of glaciers melting, their morphological types, expositions and elevations above sea level fluctuate. In some cases, glaciers number increases in parallel with the reduction in their area. That was typical for the glaciers of the Nenskra and Nakra River basins in the years of 1911-1960, when the glaciers area had reduced from $50.54 \mathrm{sq}$. km to $48.62 \mathrm{sq}$. km, and their number had increased from 54 to 75 glaciers. In the same period in the Nakra basin, the glaciers area had reduced from $20.24 \mathrm{sq}$. km to 18.49 sq. km, and their number had increased from 26 to 31 (Figure 8). In the mentioned period of time, there was a same situation for almost all of glacial basins of the southern slope of the Great Caucasus.

As for the period of 1960-2014, there was a different situation. In particular, along with a reduction of the area of glaciers, their number decreased as well. For example, in the Nenskra River basin the number of the glaciers was almost halved: it had reduced from $48.62 \mathrm{sq}$. km to $25.58 \mathrm{sq} . \mathrm{km}$, and the number of glaciers had reduced as well from 75 to 67 . A similar situation was in the Nakra basin, where the glaciers area had reduced from 18.49 sq. $\mathrm{km}$ to $10.21 \mathrm{sq}$. $\mathrm{km}$ and within the same period their number had decreased from 31 to 28 (Figure 8 ).

In the mentioned first period (1911-1960), an increase in the number of glaciers was caused by their division during the retreating of the glaciers and by the formation of small cirque type of glaciers. And in the last period of 54 years, the mentioned small cirque glaciers had melted at all, and correspondingly, in parallel with the reduction in area of the glaciers, their number also had decreased. It should be noted that the same situation was observed in almost all of glacial basins of the southern slope of the Great Caucasus.

It's to be mentioned that due to such location, Mestia cavernous and Enguri River gorge of solid precipitation aren't distinguished with great abundance (compare with the south slope of the Caucasus of Abkhazia), especially in the last years as mentioned above, for winters of 2011-2012 which were the least snowy during the years of 1960-2013. Therefore, it's likely to be one of the factors for the increased pace of glacier reduction.

\section{References}

[1] Gobejishvili, R.G., Tielidze, L.G., Lomidze, N. and Javakhishvili, A. (2012) Monitoring of Glaciers on the Background of Climate Change. Monograph, Tbilisi, “Universali” 176 p. (In Georgian)

[2] Tielidze, L.G. (2014) Glaciers of Georgia. Monograph, Tbilisi, “Color” 254 p. (In Georgian)

[3] Kordzakhia, R. (1967) Enguri and Tskhenistskhali River Basins Climate Features within the Svaneti. Acts of Georgian Geographical Society, IX-X, 110-125. (In Georgian)

[4] Podozerskiy, K.I. (1911) Glaciers of the v Caucasus Mountain Range. “Zap. KORGO”, 14, Edit. 1. (In Russian)

[5] Gobejishvili, R.G. (1995) Present Day Glaciers of Georgia and Evolution of Glaciation in the Mountains of Eurasia in Late Pleistocene and Holocene. Thesis for a Doctor's Degree, Tbilisi, 320 p. (In Georgian) 